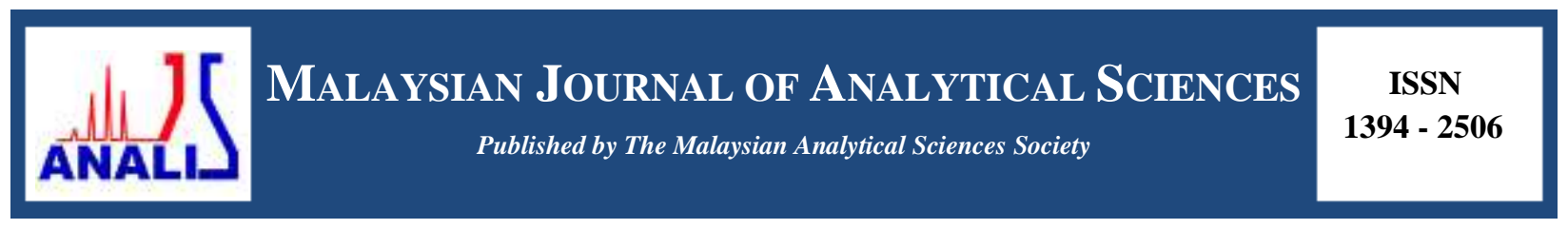

\title{
CLAMSHELL AND SEA SAND AS HETEROGENEOUS CATALYSTS FOR WASTE COOKING OIL BASED BIODIESEL PRODUCTION VIA TRANSESTERIFICATION REACTION
}

\author{
(Kulit Kerang dan Pasir Pantai Sebagai Mangkin Heterogen untuk Penghasilan Biodiesel \\ Berasaskan Minyak Masak Sawit Terpakai Melalui Tindakbalas Transesterifikasi) \\ Arsyad Ismail Sanuzi, Syuhada Mohd Tahir*, Siti Norhafiza Mohd Khazaai \\ Faculty of Applied Sciences, \\ Universiti Teknologi MARA Cawangan Pahang, 26400 Bandar Tun Abdul Razak Jengka, Pahang, Malaysia \\ *Corresponding author: syuhadamohdtahir@pahang.uitm.edu.my
}

Received: 4 December 2016; Accepted: 1 December 2017

\begin{abstract}
This study was carried out to study the effectiveness of clamshell and sea sand as heterogeneous catalyst to produce biodiesel via transesterification of waste cooking oil (WCO). WCO was first pre-treated to discard water and impurities. Clamshell and sea sand were crushed into fine powder, sieved to $500 \mu \mathrm{m}$ particles and calcined. Next, the pre-treated WCO was used to obtain fatty acid methyl ester (FAME) via transesterification reaction. FTIR and XRD results of calcined clamshell confirmed the formation of $\mathrm{CaO}$ and $\mathrm{Ca}(\mathrm{OH})_{2}$ while sea sand contains $\mathrm{SiO}_{2}$ before and after calcination. 2:1 clamshell-to-sea sand ratio produced highest FAME yield. This ratio was used to study the effect of catalyst loading amount. 7 wt $\%$ catalyst produced highest FAME yield. Increasing catalyst to $10 \mathrm{wt} \%$ reduced the FAME yield due to the soap formation. Analysis of FAME using GC-MS showed the presence of myristic acid, palmitic acid and oleic acid. This study shows that combination of clamshell and sea sand is good potential catalyst for transesterification reaction to produce biodiesel.
\end{abstract}

Keywords: biodiesel, heterogeneous catalyst, transesterification, waste cooking oil

\begin{abstract}
Abstrak
Kajian ini dijalankan untuk mengkaji keberkesanan kulit kerang dan pasir pantai sebagai mangkin heterogen untuk menghasilkan biodiesel melalui transesterifikasi minyak masak sawit terpakai (WCO). WCO dirawat terlebih dahulu untuk membuang air dan kekotoran. Kulit kerang dan pasir pantai dihancurkan menjadi serbuk halus, ditapis kepada $500 \mu \mathrm{m}$ dan dikalsinasi. Tindakbalas transesterifikasi WCO dijalankan untuk menghasilkan metil ester (FAME). Data daripada FTIR dan XRD untuk kulit kerang terkalsinasi mengesahkan pembentukan $\mathrm{CaO}$ dan $\mathrm{Ca}(\mathrm{OH})_{2}$ manakala pasir pantai pula mengandungi $\mathrm{SiO}_{2}$ sebelum dan selepas kalsinasi. Nisbah 2:1 kulit kerang terhadap pasir pantai menghasilkan FAME yang paling tinggi dan nisbah ini digunakan dalam kajian seterusnya untuk melihat kesan jumlah pemangkin terhadap jumlah FAME yang dihasilkan. Mangkin sebanyak 7 wt $\%$ menghasilkan jumlah FAME yang paling tinggi. Penggunaan mangkin sebanyak $10 \mathrm{wt} \%$ mengurangkan jumlah FAME yang diperoleh disebabkan pembentukan sabun. Analisis FAME menggunakan GC-MS menunjukkan kehadiran asid miristik, asid palmitik dan asid oleik. Kajian ini menunjukkan campuran kulit kerang dan pasir pantai adalah mangkin yang berpotensi baik untuk tindakbalas transesterifikasi untuk menghasilkan biodiesel.
\end{abstract}

Kata kunci: biodiesel, mangkin heterogen, transesterifikasi, minyak masak sawit terpakai 


\section{Arsyad Ismail et al: CLAMSHELL AND SEA SAND AS HETEROGENEOUS CATALYSTS FOR WASTE COOKING OIL BASED BIODIESEL PRODUCTION VIA TRANSESTERIFICATION REACTION}

\section{Introduction}

Biodiesel is an attractive alternative for conservative petroleum-based fuel and can be used directly in commercial diesel engines. Biodiesel is made of natural and renewable sources such as new and used vegetable oils and animal fats. Biodiesel made from edible vegetable oils have undesirable impact to the environment as they require a large amount of farmland [1]. Waste cooking oil (WCO) is an abundant, readily available and cheap raw material for biodiesel. The use of WCO can minimize biodiesel production costs up to 60-90\% [2].

Biodiesel can be produced by two methods: acid esterification and alkaline transesterification. The common catalysts for acid esterification are $\mathrm{H}_{2} \mathrm{SO}_{4}$ and $\mathrm{Fe}_{2}\left(\mathrm{SO}_{4}\right)_{3}$. Unfortunately, this method produced water along with the desired ester and inhibits transesterification of glyceride. Alkaline transesterification is more prefered method because it is 4000 times faster than acid esterification method. Two types of catalyst in alkaline transesterification are homogeneous and heterogeneous catalysts. Homogeneous catalyst $(\mathrm{NaOH}$ and $\mathrm{KOH})$ is effective and affordable but highly sensitive to water and free fatty acid content and require high energy consumption for purification [2]. Researchers have found various types of heterogeneous catalysts such as ion exchange resins, sulfated oxides, transition metal oxide, boron group, alkaline earth metal oxide, mixed metal oxide, alkali metal oxides, waste material, carbon based and enzyme based [2]. Heterogeneous catalysts are environmentally friendly, economical and have high chance for heat integration [3].

$\mathrm{CaO}$, an alkaline earth metal oxides is an ionic crystal and is an established heterogeneous catalyst. The Lewis acidity of the metal cation due to its modest electronegativity makes it a good heterogeneous catalyst [4]. The conjugated oxygen anions in the crystal structure posses strong basic property. In this study, clamshell was chosen as the renewable resource for $\mathrm{CaO}$. Clamshell has high content of calcium carbonate $\left(\mathrm{CaCO}_{3}\right)$, when calcined at proper temperature, will be converted into $\mathrm{CaO}$. In this study, $\mathrm{CaO}$ from clamshell will be combined with $\mathrm{SiO}_{2}$ from seasand in order to increase the catalytic effectiveness.

\section{Materials and Methods}

The clamshells were cleaned and dried in oven at $105^{\circ} \mathrm{C}$ for 24 hours and crushed into a fine powder. Next, the powder was sieved through $500 \mu \mathrm{m}$. The powder obtained was then calcined in a furnace at $900^{\circ} \mathrm{C}$ for 3.5 hours [5]. The sea sand was rinsed, dried, screened to extract larger particles and sieved through $500 \mu \mathrm{m}$. Then, sea sand was calcined at $800{ }^{\circ} \mathrm{C}$ for 2 hours [6]. The catalysts were characterized by using FTIR and XRD.

WCO sample was collected from a restaurant at Bandar Pusat Jengka, Pahang. WCO was first filtered to remove suspended solid particles and heated at $80{ }^{\circ} \mathrm{C}$. Then, the oil was washed with water (approximately $10 \%$ of the oil volume) and centrifuged at $600 \mathrm{rpm}$ for 10 minutes to remove water soluble salt impurities. Lastly, the organic phase collected and kept under vacuum at $80^{\circ} \mathrm{C}$ for 30 minutes to remove water [6].

Transesterification process carried out in three-necked round bottom flask equipped with reflux, thermometer and magnetic stirrer. WCO and methanol with a molar ratio of $1: 12$ were mixed with catalyst and refluxed at $\quad 60{ }^{\circ} \mathrm{C}$ for 6 hours at $600 \mathrm{rpm}$. The solid catalyst was separated by filtration afterwards. The resulting liquid was placed in a separatory funnel and left for 24 hours at room temperature, until two layers were formed. The top layer was FAME in methanol and the bottom layer was glycerol. The methanol layer was collected and evaporated in a rotary evaporator to obtain the biodiesel (FAME). Table 1 shows the catalysts composition used in this study to observe the effect of catalyst ratio for $5 \mathrm{wt} \%$ weight of catalyst over weight of WCO. The optimum ratio with highest yield of biodiesel was used to further study on the effect of loading amount of the catalyst at 7 and $10 \mathrm{wt} \%$. All temperature and time taken for transesterification reaction were kept constant.

FTIR spectra were recorded using Spectrum 100, Perkin Elmer, in the range of 450-4000 $\mathrm{cm}^{-1}$ wavenumbers. The catalysts were characterized before and after calcined using XRD model D-5000 Siemen. The data was collected at diffraction angle $2 \theta$ from $3^{\circ}$ to $80^{\circ}$ at the rate of $0.04 \mathrm{~s}^{-1}$. The FAME was analyzed with gas chromatography-mass spectrometry (GC-MS) using Agilent 5977A MSD Mass Spectrometer/Data System at initial temperature of $125^{\circ} \mathrm{C}$ for 4 min $15^{\circ} \mathrm{C}$ per minute temperature increment until reaching final temperature at $275^{\circ} \mathrm{C}$ [7]. 
Table 1. Catalysts composition used for $5 \mathrm{wt} \%$ weight of catalyst over weight of WCO

\begin{tabular}{lccc}
\hline $\begin{array}{l}\text { Weight of Catalyst } \\
\text { Over Weight of WCO } \\
(\%)\end{array}$ & $\begin{array}{c}\text { Clamshell-to-Sea } \\
\text { Sand Ratio }\end{array}$ & $\begin{array}{c}\text { Clamshell } \\
(\mathrm{g})\end{array}$ & $\begin{array}{c}\text { Sea Sand } \\
(\mathrm{g})\end{array}$ \\
\hline & $1: 0$ & 0.50 & 0 \\
& $0: 1$ & 0 & 0.50 \\
5 & $1: 1$ & 0.25 & 0.25 \\
& $1: 2$ & 0.17 & 0.33 \\
& $2: 1$ & 0.33 & 0.17 \\
\hline
\end{tabular}

Results and Discussion

Figure 1 shows the FTIR spectrum and the absorption peaks of uncalcined and calcined clamshell, respectively. Uncalcined clamshell showed three main absorption peaks belongs to three vibration modes for $\mathrm{CO}_{3}{ }^{2-}$ molecule; asymmetric stretch, out-of plane bend and in-plane bend. During calcination, $\mathrm{CaCO}_{3}$ will decompose into $\mathrm{CaO}$ and $\mathrm{CO}_{2}$, as shown in equation 1 [8]. Exposure of $\mathrm{CaO}$ to atmospheric air cause the formation of $\mathrm{Ca}(\mathrm{OH})_{2}$ as shown in equation 2, hence a sharp $\mathrm{OH}$ bond stretching band observed at $3640 \mathrm{~cm}^{-1}$ [5]. The presence of $\mathrm{CaO}$ and $\mathrm{OH}$ absorption peaks prove the complete decomposition of $\mathrm{CaCO}_{3}$ at the chosen calcination temperature.

$$
\begin{aligned}
& \mathrm{CaCO}_{3} \rightarrow \mathrm{CaO}+\mathrm{CO}_{2} \\
& \mathrm{CaO}+\mathrm{H}_{2} \mathrm{O} \rightarrow \mathrm{Ca}(\mathrm{OH})_{2}
\end{aligned}
$$

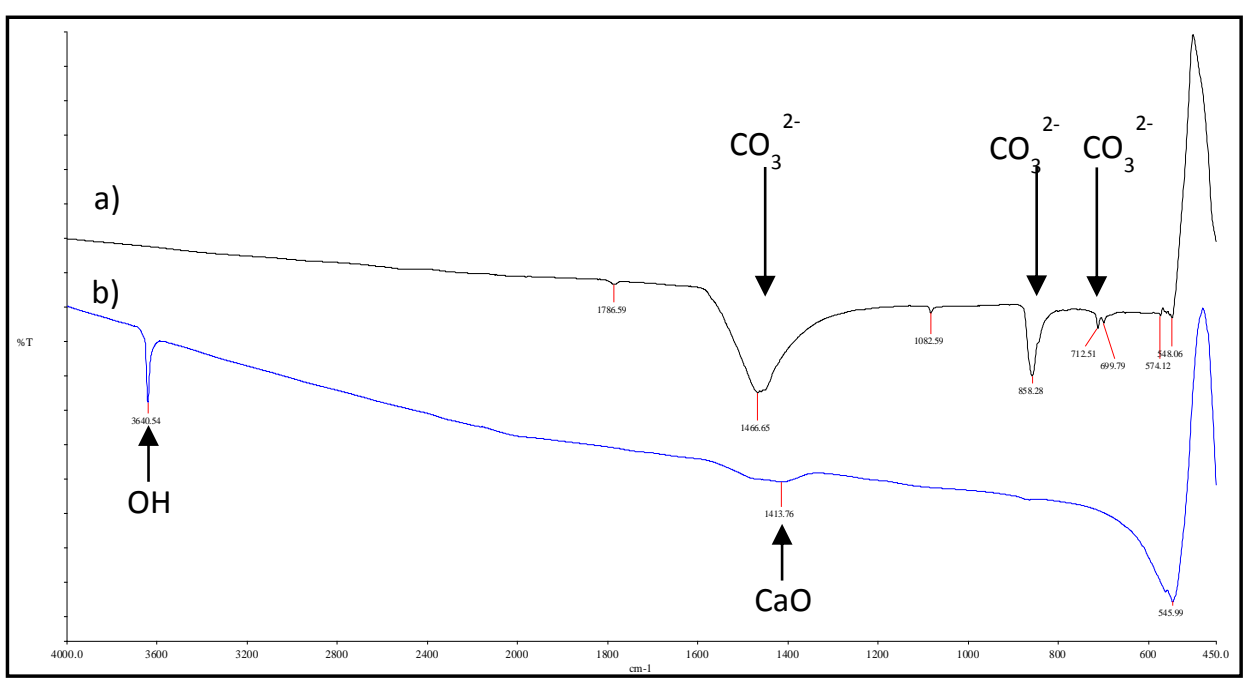

Figure 1. FTIR spectra of clamshell; (a) uncalcined and (b) calcined

FTIR spectrum of uncalcined and calcined sea sand in Figure 2 shows an almost similar absorption peaks, means calcination did not change the chemical structure of sea sand and calcination was not necessary. The four major absorption peaks observed were classified as quartz or silicon dioxide, $\mathrm{SiO}_{2}$. The peaks at $778.84 \mathrm{~cm}^{-1}$ and 777.95 $\mathrm{cm}^{-1}$ refers to Si-O symmetrical stretching vibration while $1086.93 \mathrm{~cm}^{-1}$ and $1084.92 \mathrm{~cm}^{-1}$ refers to Si-O asymmetrical stretching [9]. 


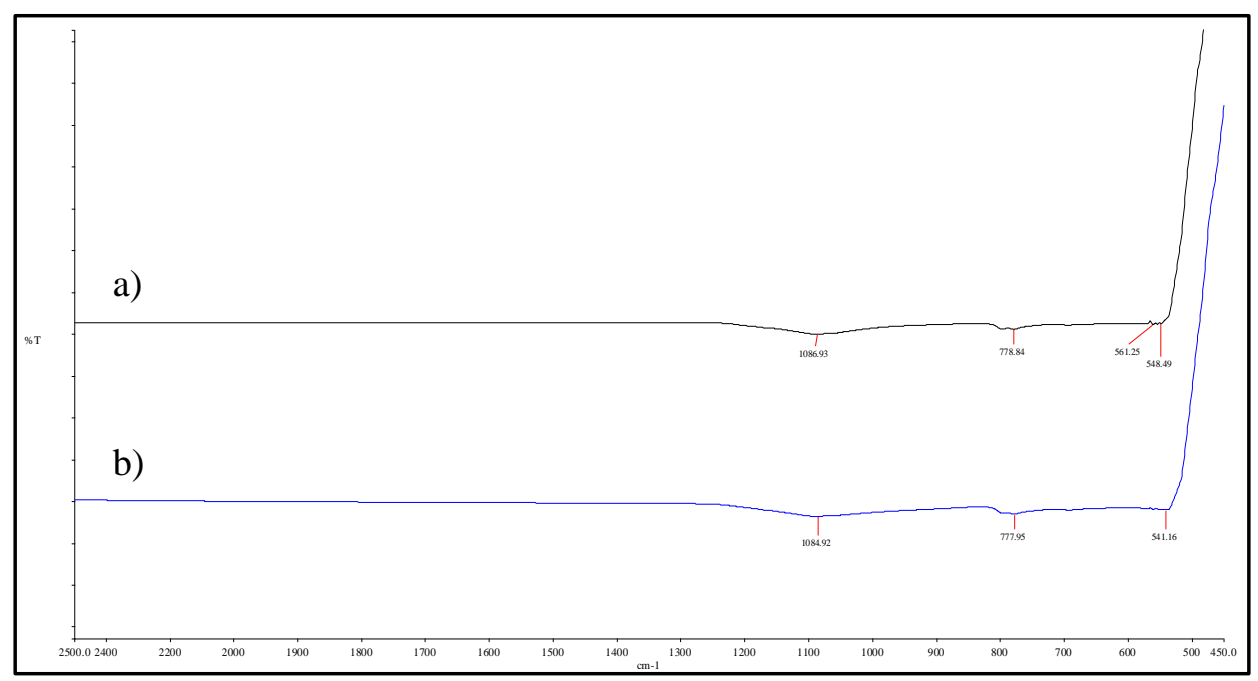

Figure 2. The FTIR spectra of sea sand; a) uncalcined and b) calcined

Figure 3 represents the XRD diffractograms for uncalcined and calcined clamshell. The result revealed that the composition of uncalcined clamshell dominantly consists of $\mathrm{CaCO}_{3}$ (aragonite). The diffraction peaks for $\mathrm{CaCO}_{3}$ can be observed at $2 \theta=26.34^{\circ}, 33.24^{\circ}$ and $45.93^{\circ}$. After calcination at $900^{\circ} \mathrm{C}, \mathrm{CaCO}_{3}$ completely transformed into $\mathrm{CaO}$ by releasing $\mathrm{CO}_{2}$. The peaks of $\mathrm{CaO}$ (lime syn) appeared at $2 \theta=32.38^{\circ}, 37.52^{\circ}$, and $53.98^{\circ}$ with (111), (200) and (220) orientations. In addition, $\mathrm{Ca}(\mathrm{OH})_{2}$ (portlandite) also observed at $2 \theta=18.16^{\circ}$ and $34.26^{\circ}$ due to hydration of $\mathrm{CaO}$ by atmospheric moisture [10]. These XRD result proves the calcination temperature of clamshell, $900{ }^{\circ} \mathrm{C}$ for 3.5 hours was suitable to completely decompose $\mathrm{CaCO}_{3}$ into $\mathrm{CaO}$.

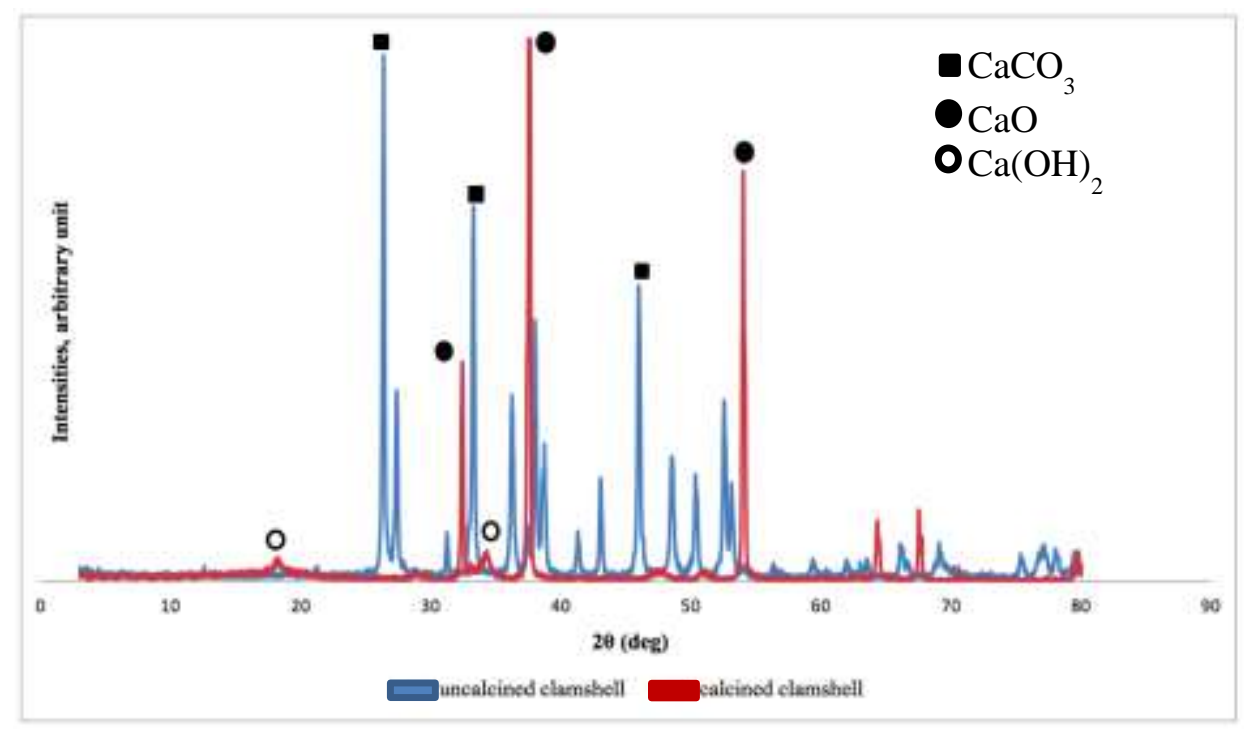

Figure 3. XRD diffractograms of uncalcined and calcined clamshell 
Figure 4 represents the XRD patterns for uncalcined and calcined sea sand. The result revealed that the composition of uncalcined sea sand dominantly consists of $\mathrm{SiO}_{2}$. These intensity diffraction peaks can be observed at $2 \theta=20.89^{\circ}$ and $26.84^{\circ}$. Meanwhile, the peaks of $\mathrm{SiO}_{2}$ for calcined sea sand were observed at $2 \theta=20.94^{\circ}$ and $26.70^{\circ} . \mathrm{SiO}_{2}$ was the major constituent due to high quartz content rather than any mineral in the sea sand. The JCPDS standard pattern number 46-1045 values for $\mathrm{SiO}_{2}$ (quartz) are $2 \theta=20.82^{\circ}$ and $26.62^{\circ}$.

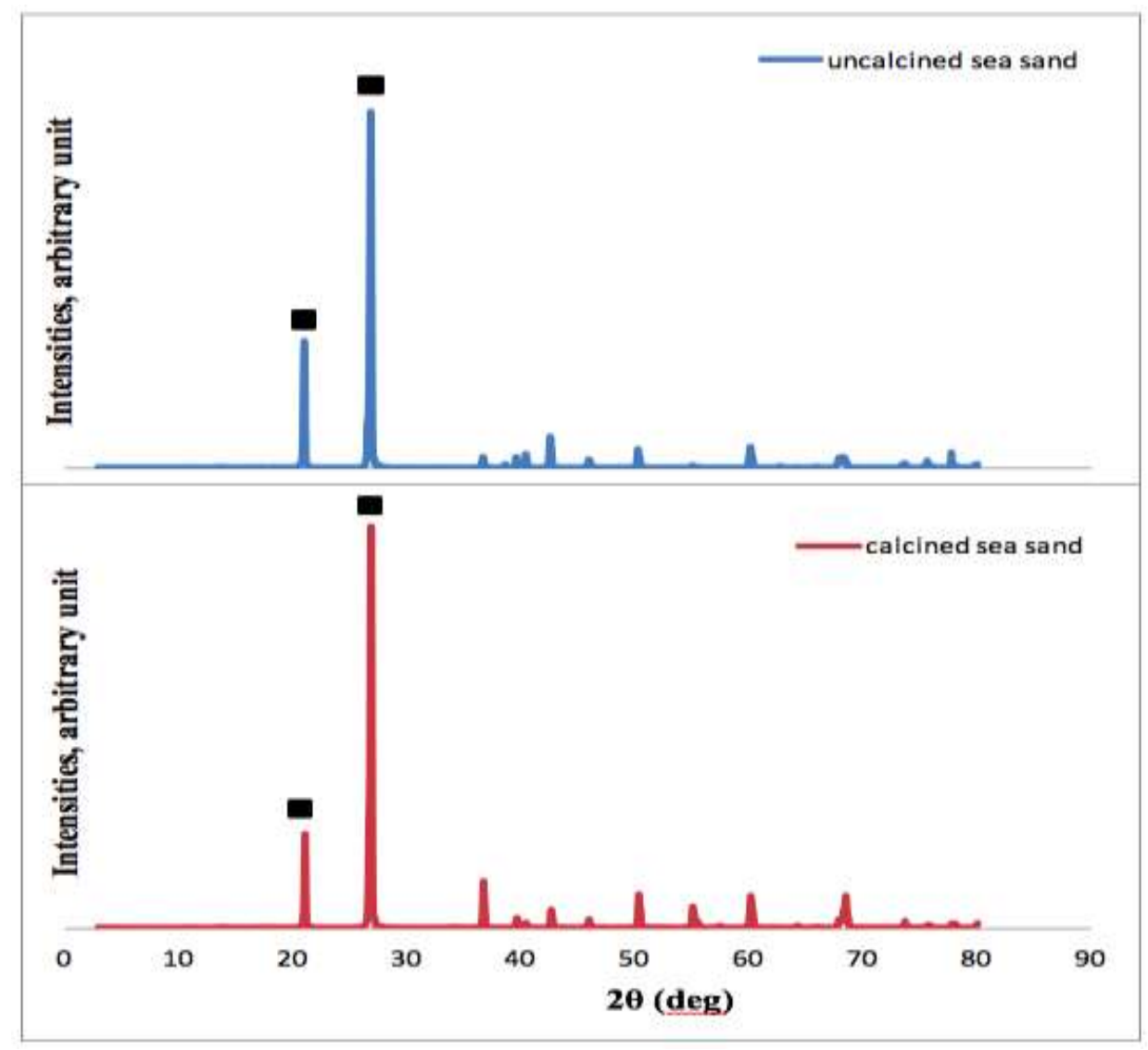

Figure 4. XRD diffractograms of uncalcined sea sand and calcined sea sand $\left(\mathbf{Q}: \mathrm{SiO}_{2}\right)$

According to GC-MS result, each samples of FAME produced contain palmitin. Their peak ranges between 10.00 12.00 minutes. Uzun et al. [11] stated that five properties of WCO-based FAME is myristic acid, palmitic acid, oleic acid, linolenic acid, and linoleic acid. However, the column for GC-MS instrument used in this study only capable to detect three of them; myristic acid, palmitic acid and oleic acid. Figure 5 shows the GC-MS spectra of FAME obtained and detailed in Table 2. 


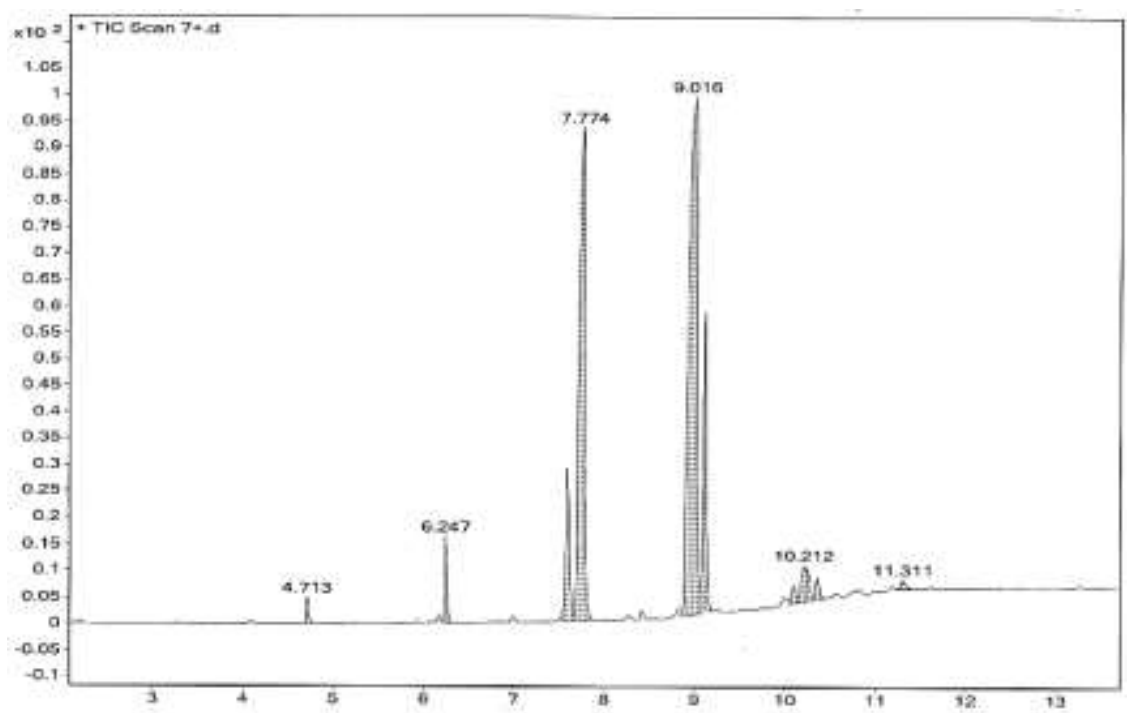

Figure 5. GC-MS spectrum of FAME using 7 wt $\%$ loading amount with 2:1 clamshell-to-sea sand ratio

Table 2. The scan range of FAME properties 2:1 clamshell-to-sea sand ratio

\begin{tabular}{lccc}
\hline \multirow{2}{*}{ Properties } & \multicolumn{3}{c}{ Scan Range (minutes) } \\
\cline { 2 - 4 } & $\mathbf{5} \mathbf{~ w t} \%$ & $\mathbf{7 ~ w t \%}$ & $\mathbf{1 0} \mathbf{~ w t \%}$ \\
\hline Palmitic acid & 7.774 & 7.774 & 7.775 \\
Oleic acid & $9.016,9.113$ & $9.016,9.101$ & $9.011,9.112$ \\
Stearic acid & - & - & - \\
Myristic acid & 6.247 & 6.247 & 6.247 \\
Lauric acid & 4.713 & 4.713 & 4.714 \\
Palmitoleic acid & 7.597 & 7.597 & 7.592 \\
Ascorbic acid & - & - & - \\
Palmitin & $10.224,11.317$ & $10.212,11.311$ & $10.212,11.317$ \\
Glycidyl palmitate & - & - & - \\
Glycidyl oleate & - & - & - \\
Cyclopropanebutanoic acid & - & - & - \\
\hline
\end{tabular}

To observe the effect of clamshell-to-sea sand ratio on FAME production, five ratios were chosen; 1:0, 0:1, 1:1, 1:2, and 2:1. Loading amount used was fixed at $5 \mathrm{wt} \%$. The result shown in Figure 6. It was found that the highest percentage FAME yield obtained was $71.1 \%$ with clamshell-to-sea sand ratio of 2:1. This result shows that the combination of two catalysts increase the percentage yield significantly and the greater amount of clamshell in the catalyst ratio gave higher biodiesel yield. The presence of $\mathrm{CaO}$ and $\mathrm{Ca}(\mathrm{OH})_{2}$ in the calcined clamshell was believed as the factor. $\mathrm{O}^{2-}$ in $\mathrm{CaO}$ and $\mathrm{OH}^{-}$in $\mathrm{Ca}(\mathrm{OH})_{2}$ are the adsorptive sites that will extract $\mathrm{H}^{+}$from methanol to form methoxide anions that will then react with the fatty acid in triglyceride molecules to form FAME. 


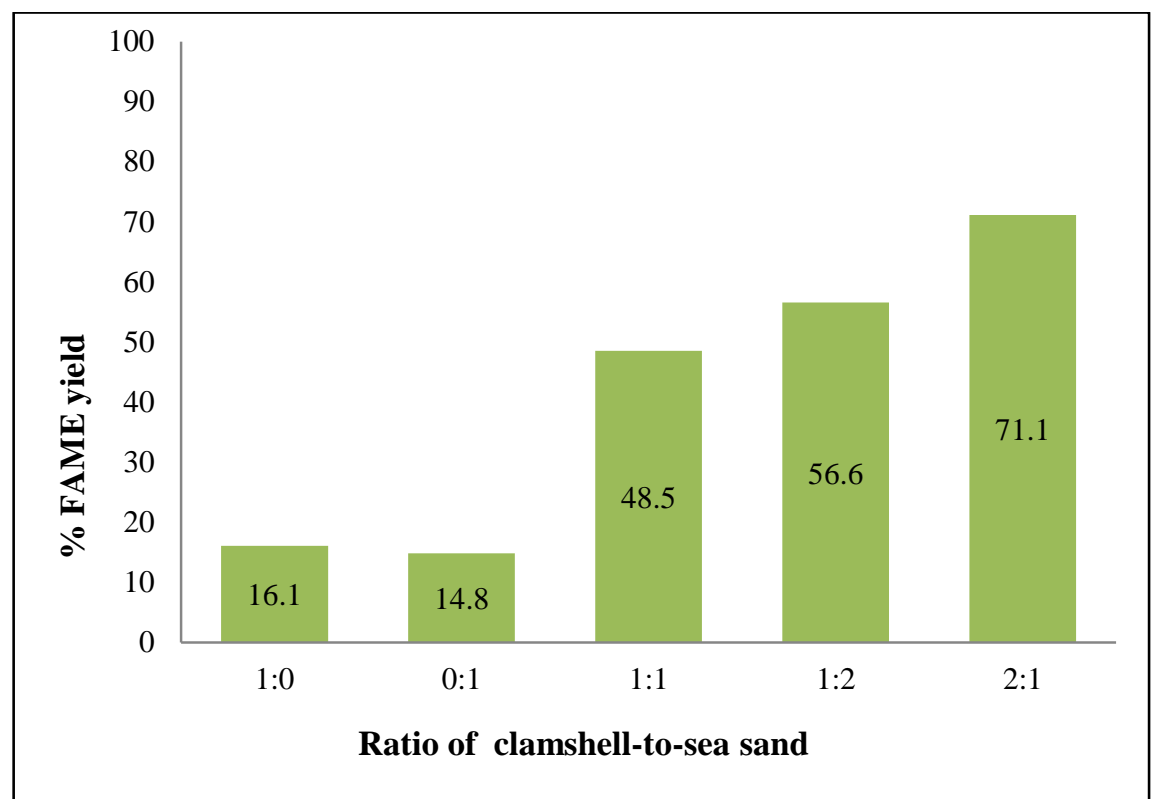

Figure 6. Effect of clamshell-to-sea sand ratio on FAME yield using $5 \mathrm{wt} \%$ catalyst loading

The clamshell-to-sea sand ratio of 2:1 was used to further study the effect of catalyst loading on FAME production. As shown in Figure 7, $7 \mathrm{wt} \%$ loading amount of the catalysts produced highest FAME yield of 75.3\%. Increasing the loading amount from 5 to $7 \mathrm{wt} \%$ increase the percentage yield but further increase to $10 \mathrm{wt} \%$ reduced the yield. High basicity in $\mathrm{CaO}$ and $\mathrm{Ca}(\mathrm{OH})_{2}$ helps in breaking the bond of free fatty acid chain with glycerol in producing FAME. Insufficient catalyst dosage will reduce the breaking process results in incomplete transesterification and reduce the FAME yield. FAME yield increased with the increase in the catalyst loading amount since more triglyceride molecules will be broken. However, excess alkaline catalyst loading could results in more triglyceride participation leading to soap formation and thus decrease biodiesel yield especially in a longer retention time [12].

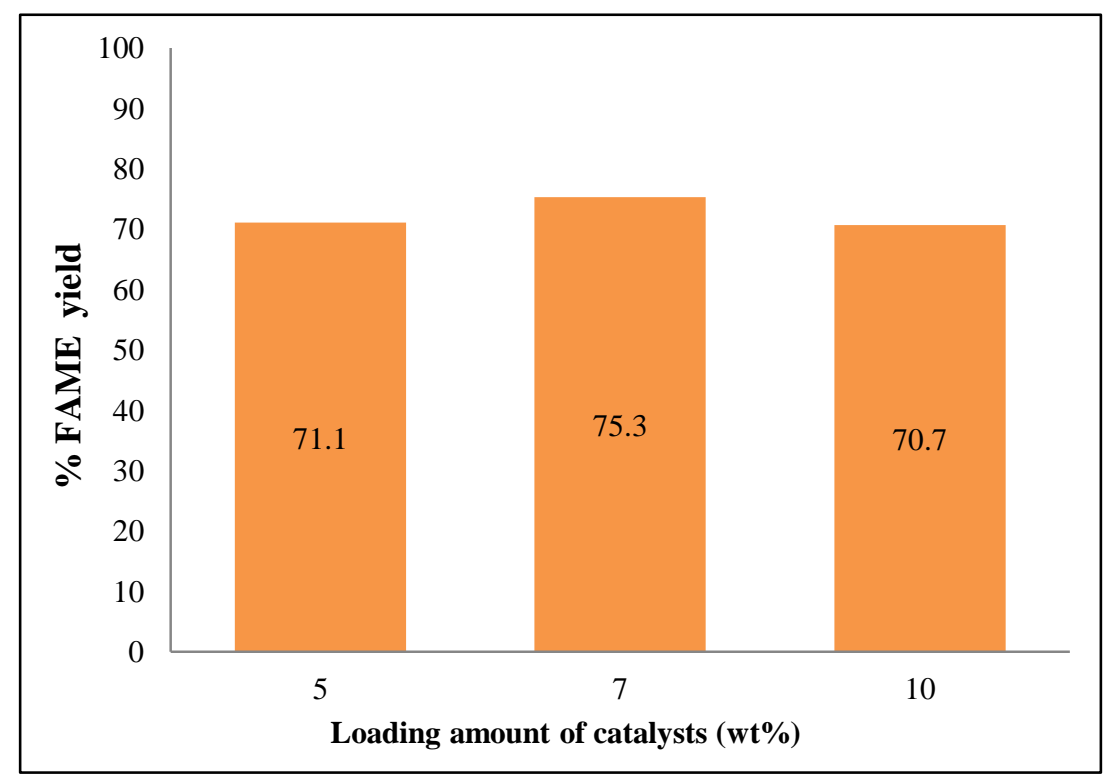

Figure 7. Effect of loading amount of catalyst on FAME yield using 2:1 clamshell-to-sea sand ratio 


\section{Arsyad Ismail et al: CLAMSHELL AND SEA SAND AS HETEROGENEOUS CATALYSTS FOR WASTE COOKING OIL BASED BIODIESEL PRODUCTION VIA TRANSESTERIFICATION REACTION}

\section{Conclusion}

Waste cooking oil-based biodiesel (FAME) was produced via transesterification reaction. The effect of ratio and loading amount of combination of alkaline heterogeneous catalyst; clamshell as source of $\mathrm{CaO}$ and sea sand as source of $\mathrm{SiO}_{2}$ was studied. FTIR and XRD results showed the calcination of clamshell at $900{ }^{\circ} \mathrm{C}$ for 3.5 hours were suitable to completely decompose $\mathrm{CaCO}_{3}$ into $\mathrm{CaO}$. Presence $\mathrm{Ca}(\mathrm{OH})_{2}$ also observed as the result of reaction of $\mathrm{CaO}$ with atmospheric moisture. Combination of two catalysts was found to increase the percentage yield significantly and the greater amount of clamshell in the catalysts ratio gave higher FAME yield. The optimum ratio for clamshell-to-sea sand was 2:1 and this ratio was used to study the effect of loading amount of the catalysts in FAME percentage yield. Increasing the loading amount from 5 to $7 \mathrm{wt} \%$ increase the percentage yield but further increase to $10 \mathrm{wt} \%$ loading amount reduced the yield due to the soap formation especially in a longer retention time. $7 \mathrm{wt} \%$ loading amount of the catalysts produced highest FAME yield of $75.3 \%$. In conclusion, combination of clamshell and sea sand possesses good potential as heterogeneous catalyst in WCO-based FAME production.

\section{Acknowledgements}

The authors would like to thank Universiti Teknologi MARA and Ministry of Higher Education, Malaysia for research grant no RAGS/1/2014/SG01/UITM//3.

\section{References}

1. Mandolesi de Araújo, C. D., de Andrade, C. C., de Souza, E., Silva, E. and Dupas, F. A. (2013). Biodiesel production from used cooking oil: A review. Renewable and Sustainable Energy Reviews, 27: 445-452.

2. Talebian-Kiakalaieh, A., Amin, N. A. S. and Mazaheri, H. (2013). A review on novel processes of biodiesel production from waste cooking oil. Applied Energy, 104: 683-710.

3. Aransiola, E. F., Ojumu, T. V., Oyekola, O. O., Madzimbamuto, T. F. and Ikhu-Omoregbe, D. I. O. (2014). A review of current technology for biodiesel production: State of the art. Biomass and Bioenergy, 61: 276-297.

4. Kouzu, M. and Hidaka, J. S. (2012). Transesterification of vegetable oil into biodiesel catalyzed by CaO: A review. Fuel, 93: 1-12.

5. Nair, P., Singh, B., Upadhyay, S. N. and Sharma, Y. C. (2012). Synthesis of biodiesel from low FFA waste frying oil using calcium oxide derived from Mereterix mereterix as a heterogeneous catalyst. Journal of Cleaner Production, 29-30: 82-90.

6. Muciño, G. G., Romero, R., Ramírez, A., Martínez, S. L., Baeza-Jiménez, R. and Natividad, R. (2014). Biodiesel production from used cooking oil and sea sand as heterogeneous catalyst. Fuel, 138: 143-148.

7. Nyoman, P. A., Santi, D. S., Suprapto Kusno, B. and Achmad, R. (2012). Development of heterogeneous alumina supported base catalyst for biodiesel production. 3rd international conference on biology, environment and chemistry, IACSIT Press, Singapore, V46. 25, 117-120.

8. El-Gendy, N. S., Deriase, S. F., Hamdy, A. and Abdallah, R. I. (2015). Statistical optimization of biodiesel production from sunflower waste cooking oil using basic heterogeneous biocatalyst prepared from eggshells. Egyptian Journal of Petroleum, 24: 37-48.

9. Sivakumar, S., Ravisankar, R., Raghu, Y., Chandrasekaran, A. and Chandramohan, J. (2012). FTIR spectroscopic studies on coastal sediment samples from cuddalore district, Tamilnadu, India. Indian Journal of Advances in Chemical Science, 1: 40-46.

10. Jaiyen, S., Naree, T. and Ngamcharussrivichai, C. (2015). Comparative study of natural dolomitic rock and waste mixed seashells as heterogeneous catalysts for the methanolysis of palm oil to biodiesel. Renewable Energy, 74: 433-440.

11. Uzun, B. B., Kılıç, M., Özbay, N., Pütün, A. E. and Pütün, E. (2012). Biodiesel production from waste frying oils: Optimization of reaction parameters and determination of fuel properties. Energy, 44(1): 347-351.

12. Sirisomboonchai, S., Abuduwayiti, M. and Guan, G. (2015). Biodiesel production from waste cooking oil using calcined scallop shell as catalyst. Energy Conversion and Management, 95: 242-247. 